\title{
István Mészáros: \\ Um breve comentário de \\ "O desafio e o fardo do tempo histórico"
}

Ricardo Antunes*

$\mathrm{O}$ filósofo marxista István Mészáros é um autor referencial para tantos que lutam contra a lógica destrutiva que preside o mundo contemporâneo. Aluno e colaborador direto do filósofo húngaro Georg Lukács, com quem trabalhou diretamente na Universidade de Budapeste, na primeira metade dos anos 1950, tornou-se, dentre todos os antigos colaboradores de Lukács, o que mais efetivamente contribuiu para a realização de uma obra original, crítica e devastadora em relação às tantas mistificações hoje presentes.

Mészáros iniciou sua vida como operário na Hungria. Quando chegou à universidade, destacou-se pelo brilhantismo, competência e radicalidade. Sempre calibrando a atuação na universidade com as necessidades vitais da humanidade e a busca de sua transformação tornou-se desde logo um espírito anticapitalista excepcional.

Dotado de erudição enciclopédica, domina economia política, filosofia, teoria social e literatura como poucos. Sua obra dialoga criticamente com toda a produção relevante neste século, navegando dos clássicos aos contemporâneos, dotado de uma força invejável. Uma breve passagem por sua vasta produção seria bom exemplo. Mas basta dizer que seus livros Marx's Theory of Alienation (1970), The Power of Ideology (1989) e Beyond Capital (1995) - todos

* Professor Titular de Sociologia do IFCH/UNICAMP e autor de 0 caracol e sua concha (Boitempo), Os Sentidos do Trabalho (Boitempo), Uma Esquerda Fora do Lugar (Autores Associados), Adeus ao Mundo do Trabalho? (Cortez), dentre outros livros. Coordenador da coleção Mundo do Trabalho (Boitempo editorial), que vem publicando as principais obras de István Mészáros no Brasil. 
publicados pela Coleção Mundo do Trabalho, que coordenamos na Boitempo $^{1}$ - apareceram em diversos países, do Norte ao Sul do mundo, incluindo a China, a Índia, o Japão, Oriente Médio, e foram reeditados inúmeras vezes.

István Mészáros é Professor Emeritus da Universidade de Sussex (Inglaterra). Trabalhou também em universidades na Escócia, Itália, Canadá e México, e sua obra ecoa em várias partes do mundo, despertando sempre crescente interesse. Seria impossível, neste breve comentário, falar de tantas teses e proposições que marcam sua trajetória. Destaco, então, algumas de suas formulações mais significativas, dotadas de enorme originalidade em seu pensamento.

O conjunto da obra de István Mészáros é uma crítica devastadora às engrenagens que caracterizam o sistema do capital. Em Para Além do Capital o autor, fortemente inspirado em Marx e em contraste com a totalidade da literatura sobre o tema, oferece uma distinção que será central entre capital e capitalismo. O capital é anterior ao capitalismo e é a ele também posterior. O capitalismo é uma das formas de realização do capital, a forma dominante nos últimos três séculos. Mas, assim como existia capital antes do capitalismo, há capital após o capitalismo.

Sua propositura apresenta, então, o que o autor denomina como capital pós-capitalista, vigente na URSS e demais países do Leste Europeu, durante várias décadas deste século XX. Estes países, embora pós-capitalistas, foram, entretanto, incapazes de romper com o domínio do capital. Isso porque, para Mészáros, o sistema de metabolismo social do capital tem seu núcleo central formado pelo tripé capital, trabalho assalariado e Estado, três dimensões fundamentais e inter-relacionadas, sendo impossível superar o capital sem a eliminação do conjunto dos elementos que compreende este sistema. Não basta, portanto, eliminar um ou mesmo dois dos pólos do sistema do capital, mas é preciso eliminar os seus três pólos. Essa tese tem uma força explicativa que contrasta com tudo que se escreveu até o presente sobre o desmoronamento da URSS, sendo também uma pista rica para se mergulhar no enigma chinês dos dias atuais.

1 A teoria da alienação em Marx (2006), O poder da ideologia (2004) e Para além do capital (2002), respectivamente. (N.E.). 
Uma segunda formulação decisiva pode ser desse modo indicada: o sistema sócio-metabólico do capital, não tendo limites para a sua expansão, acaba por tornar-se incontrolável e essencialmente destrutivo. A produção e o consumo supérfluos, a destruição ambiental em escala global, o desemprego e a precarização do trabalho, ambos estruturais, são exemplares. Expansionista, destrutivo e, no limite, incontrolável, a forma dominante do sistema do capital é, então, a da crise endêmica, cumulativa, crônica e permanente, o que (re) coloca, como imperativo atual, frente ao espectro da destruição global - para não falar da política dos EUA de "guerra permanente" - a alternativa socialista. Mais um claro contraste com quase tudo que conforma a mesmice do pensamento dominante.

Em O Desafio e o Fardo do Tempo Histórico, seu livro novo, cujo primeiro lançamento foi realizado na UFSC (Florianópolis, 20 de novembro de 2007) - e não estamos falando somente em lançamento no Brasil, mas o primeiro de todos, uma vez que a edição brasileira foi publicada antes mesmo da edição em inglês da Monthly Review Press - Mészáros aprofunda a análise, com ênfase na sua temporalidade:

"Indivíduo nenhum e nenhuma forma concebível de sociedade hoje ou no futuro podem evitar as determinações objetivas e o correspondente fardo do tempo histórico, bem como a responsabilidade que necessariamente emerge de ambos. Em termos gerais, talvez a maior acusação contra nossa ordem social dada é que ela degrada o fardo inescapável do tempo histórico significativo - o tempo de vida tanto dos indivíduos como da humanidade - à tirania do imperativo do tempo reificado do capital, sem levar em conta as consequiências" (MÉSZÁROS, 2007, p. 33).

\section{E acrescenta:}

"O modo historicamente único de reprodução sociometabólica do capital degrada o tempo porque a determinação objetiva mais fundamental de sua forma própria de intercâmbio humano é a condução irreprimível à contínua auto-expansão, definida pelas características intrínsecas a esse modo de intercâmbio societário como a necessária expansão do capital, alcançada na sociedade de troca apenas por meio da exploração do tempo de trabalho. O capital, portanto, deve tornar-se cego com relação a todas as dimensões do tempo 
diversas da dimensão relativa ao trabalho excedente explorado ao máximo e o correspondente tempo de trabalho (ibidem)".

E, mesmo correndo o risco do exagero nesta breve apresentação, acrescento, sempre segundo Mészáros:

"O capital não pode tolerar limites a seu próprio modo de reprodução sociometabólica. Por conseguinte, considerações sobre o tempo lhe são completamente inadmissíveis... Nem mesmo quando as condições devastadoras já são patentemente óbvias, tanto no campo da produção como no terreno da ecologia. A única modalidade de tempo em que o capital pode se interessar é o tempo de trabalho explorável. Isso se verifica mesmo quando a exploração cruel do tempo de trabalho se torna um anacronismo histórico, em virtude do desenvolvimento potencial da ciência e da tecnologia a serviço da necessidade humana. Contudo, uma vez que o capital não pode contemplar essa alternativa, [ele] se torna o inimigo da história" (idem, p. 25).

O desdobramento propositivo da obra meszariana é contundente: qualquer tentativa de superar este sistema de metabolismo social que se restrinja à esfera institucional e parlamentar está fadada à derrota. Só um vasto movimento de massas, radical e extraparlamentar, pode ser capaz de destruir o sistema de domínio social do capital e sua lógica destrutiva.

Muitas outras proposições poderiam ser indicadas, mas creio que a conferência apresentada por István Mészáros é mais que suficiente para delinear a força e a vitalidade de sua obra. Sugiro que os jovens estudantes aceitem o convite para ler uma das criações mais originais, instigantes e críticas, elaboradas por um autor assumidamente de esquerda, neste período que (quase) se parece com o tempo das trevas. Até porque, conforme se pode constatar da leitura deste novo e denso livro de István Mészáros ( $O$ Desafio e o Fardo do Tempo histórico), a humanidade não tem mais muito tempo pela frente... 